\title{
MINI RISET
}

Analisis Manajemen Pemasaran Adinda Konveksi Selama Pandemi Covid 19

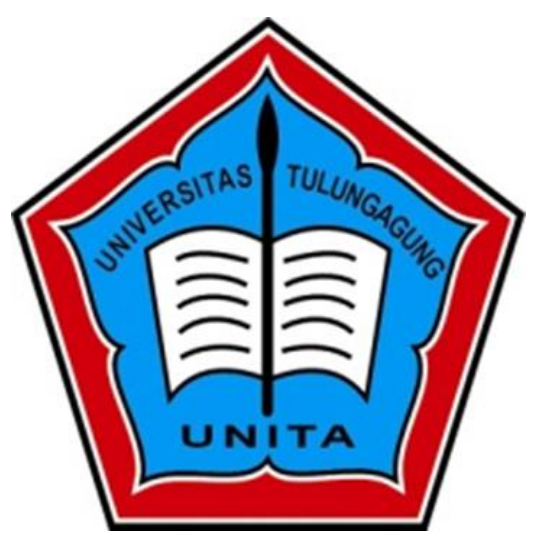

PINDA ANGGELINA (1760301100011)

GALIH CAHYO SANTIKO (1760301100021)

\author{
FAKULTAS EKONOMI
}

UNIVERSITAS TULUNGAGUNG

2020 


\title{
ANALISIS MANAJEMEN PEMASARAN ADINDA KONVEKSI SELAMA PANDEMI COVID 19
}

\begin{abstract}
Abstrak
Penulis akan meneliti bagaimana strategi Adinda Konveksi salah satu UMKM yang ada di Indonesia untuk mempertahankan UMKMnya selama pandemi covid 19. Tujuan dari penelitian ini adalah untuk mengetahui bagaimana strategi Adinda Konveksi dalam memenej pemasaran produknya selama pandemi Covid 19 ini. Penelitian yang dianalisis kali ini mengguankan metode kualitatif dan melalui pendekatan secara deskriptif. Peneliti akan menggunakan metode interview atau wawancara mendalam, observasi langsung, dan dokumen dokumen pendukung yang dibutuhkan untuk mengumpulkan data selama penelitian. Hasil dari penelitian ini adalah UMKM Adinda Konveksi menggunakan media online untuk menejemen pemasarannya karena memang dimasa pendemi ini diberlakukannya sosial distancing sehingga media online adalah media yang sangat efektif untuk mempertahankan bisnisnya
\end{abstract}

Kata kunci : Menejemen, Pemasaran, UMKM Adinda Konveksi, pandemi covid 19

\section{Pendahuluan}

Pndemi covid 19 telah membuat seluruh aktivitas dalam sektor bisnis dan perekonomoian mengalami pemrosotan yang signifikan. Akibatnya banyak sekali UMKM atau usaha keci yang terpaksa tutup dan tidak berlanjut. Organisation For Economic Co-Operation And Development (OECD) melaporkan bahwa pandemi ini berdampak pada ancaman krisis ekonomi yang cukup besar di dunia khususnya di Indonesia. Hal ini ditandai dengan kegiatan produksi yang berhenti di banyak negara, penurunan tingkat konsumsi masyarakat atau masyarakat mulai menghemat, hilangnya kepercayaan konsumen, dan penurunan pasar saham yang pada akhirnya bermuara pada Kepastian. Jika situasi ini berlanjut, OECD 
memperkirakan bahwa tingkat output di banyak negara akan turun seperlima menjadi seperempat, sementara belanja konsumen mungkin turun sekitar sepertiga karena konsumen lebih memilih berhati hati untuk menggunakan uang mereka. Produksi tersebut tentunya akan mengancam seluruh perekonomian nasional Indonesia.

Menurut pandangan dari Aknolt Kristian Pakpahan Indonesia memiliki tiga dampak terhadap pandemi covid 19 yaitu pariwisata, perdagangan dan investasi. Indonesia didominasi oleh usaha mikro, kecil dan menengah (UMKM) sebagai pusat perekonomian nasional, dan juga terkena dampak dari pandemi ini yang cukup serius. Tidak hanya dari segi nilai output bruto dan nilai perdagangan, tetapi juga jumlah pekerja yang kehilangan pekerjaan ada yang di phk atau ada yang menutup usaha kecilnya akibat pandemi yang belum ditemukan titik terang ini. Menurut data Kementerian Koperasi dan Usaha Kecil dan Menengah (KemenkopUKM), Indonesia memiliki 64.194.057 UMKM (sekitar 99\% dari semua sektor usaha) pada tahun 2018, yang mempekerjakan 116.978.631 pekerja (sekitar 97\% dari total angkatan kerja di sektor tersebut). ekonomis). Riset Kementerian Keuangan menunjukkan bahwa pandemi covid 29 Sangat berdampak negatif terhadap perekonomian domestik atau dalam negri, seperti fenomena penurunan konsumsi dan daya beli oleh konsumen atau masyarakat karena penghematan yang terjadi, penurunan kinerja perusahaan baik karyawan maupun dari atasan, ancaman terhadap perbankan dan sektor keuangan, serta posisi dari UMKM sendiri.(Awali, 2020)

Dari sisi konsumsi dan daya beli, wabah ini telah mengurangi atau bahkan kehilangan pendapatan banyak pekerja sehingga mempengaruhi tingkat konsumsi dan daya beli masyarakat mereka lebih memilih menyimpan uangnya dari pada membelanjakannya. Terutama pekerja informal dan pekerja harian atau karyawan. Karena belum bisa ditentukan dan dipastikan kapan pandemi akan berakhir, sebagian besar masyarakat sangat berhati-hati dalam mengelola pengeluaran keuangannya. Hal ini menyebabkan penurunan daya beli masyarakat terhadap barang-barang konsumsi dan menekan produsen dan penjual. Kebijakan yang dibuat pemerintah pada bulan Maret 2020 selama pandemi ini adalah sosial 
distancing karena penyebaran virus corona yang sangat mudah menyebar dari individu satu ke individu lain. korban dari penyebaran virus corona ini berjumalha ratusa hingga ribuan dan terus bertambah setiap harinya. Kemudian social distancing diubah kembali menjadi Physical distancing membuat banyak sekali dampak dan pengaruh baru bagi karyawan atau pekerja harian. Pasalnya banyak sekali yang di PHK atau dirumahkan karena perusahaan besar maupun kecil banyak memilih tutup.

Pandemi covid 19 ini memberikan banyak sekali kekhawatiran bagi masyarakat. apalagi masyarakat yang menggunakan kredit atau cicilan sehingga masyarakat banyak yang mengeluhkan pandemi ini. Dari segi pengusaha UMKM mereka mengeluhkan turunnya daya beli konsumen yang signifikan. Karena memang konsumen atau masyarakat lebih memilih menghemat atau menyimpan uangnya dibandingkan membelanjakan sesuatu tidak sesuai kebutuhan. Pelalu UMKM banyak yang mengalami kerugian besar dan banyak juga yang terpaksa menutup usahanya karena memang minimnya konsumen membeli barang atau jasanya tersebut. Hal ini lah yang membuat pengusaha besar maupun pelaku UMKM sangat resah. Masyarakat Indonesia harus bisa memikul tugas yang sangat berat mulai dari menjaga kesehatan dan keselamatan hingga menjaga perekonomian untuk memenuhi kebutuhan sehari hari mereka. Lembaga international telah banyak yang memprediksi pertumbuhan ekonomi global di tahun 2020 selama masa pandemi ini. Prediksi tersebut membutuhkan perhatian yang cukup serius dari masyarakat agar bisa menciptakan strategi strategi baru dalam mempertahankan usaha selama pandemi covid 19.

Meskipun adanya pandemi ini masyarakat khususnya pelaku usaha dituntut untuk tetap cerdas dalam mencari solusi permasalahan ini. Masyarakat tetap tidak putus asa dan mencoba memanfaatkan apapun yang ada di sekitarnya untuk menambah penghasilan keuangan mereka. Banyak sekali yang menggunakan ide ide baru untuk mengatur barang dan jasa mereka sedemikian rupa agar usahanya tidak sampai tutup. Salah satunya adalah UMKM Adinda Konveksi sebuah perusahaan yang bergerak dibidang produk dan jasa pakaian atau konveksi. Adinda Konveksi membangun strategi strategi baru untuk meningkatkan pemasaran 
produknya selama pandemi ini oleh karena itu dari pemaparan pendahuluan diatas maka dalam penelitian kali ini peneliti ingin meneliti bagaimana maenejemen pemasaran Adinda Konveksi selama Pandemi covid 19 yang belum ada kepastian ini.

\section{Landasan Teori}

1. Menejemen Pemasaran

Pengertian manajemen pemasaran adalah alat analisis, perencanaan, pelaksanaan dan pengendalian proses, yang bertujuan untuk membuat, menetapkan dan memelihara transaksi yang menguntungkan dengan sasaran pasar untuk mencapai sasaran laba utama perusahaan.

Menejemen pemasaran menurut para ahli adalah

a. Menurut Kotler, 1980. Manajemen pemasaran adalah analisis pasar, perencanaan, pelaksanaan dan pengawasan rencana pada sasaran pasar, yang bertujuan untuk berkomunikasi dengan pasar sasaran untuk mencapai tujuan perusahaan. Sehingga target dan tujuan sasaran pasar bisa berjalan dengan lancar. (Kotler, 1994) ${ }^{1}$

b. Definisi Menurut pandangan Dharmmesta \& Handoko, tahun 1982 Manajemen pemasaran merupakan salah satu kegiatan utama dan sangat pokok yang dilakukan oleh pengusaha kecil maupaun perusahan yang cukup besar dalam rangka menjaga dan mempertahankan kelangsungan perusahaan, mengembangkan barang yang dijual dan memperoleh keuntungan. Proses pemasaran dimulai sebelum produksi barang dilakukan, dan tidak berakhir dengan penjualan yang merata kepada konsumen. Kegiatan pemasaran perusahaan juga harus memuaskan konsumen jika ingin melanjutkan bisnisnya, atau jika konsumen memiliki pemahaman yang lebih baik tentang perusahaan, perusahaan

\footnotetext{
${ }^{1}$ Philip Kotler, 'Marketing Management: Analysis Planning Implementation and Control', Journal of Retailing, 88(3) (1994)
} 
harus bisa mengambil hati para konsumennya untuk tetap membeli diperusahaan tersebut (Chochoy, 2014). ${ }^{2}$

c. Menurut Kotler dan Amstrong Manajemen pemasaran adalah analisis, perencanaan, implementasi dan pengendalian rencana untuk target pasar, yang bertujuan untuk menciptakan, membangun dan memelihara komunikasi yang menguntungkan dengan pembeli atau konsumen sebagai sasaran untuk mencapai target serta tujuan perusahaan. (Thomas, 1967) ${ }^{3}$

d. American Marketing Association, Adapun penjabaran dari definisi pemasaran adalah sebagai berikut: Pemasaran merupakan suatu cara pelaksanaan dalam dunia bisnis yang mengalirkan barang dan jasa dari produsen ke konsumen, pembeli atau pengguna. Definisi yang telah dipaparkan ini hanya menekankan pada aspek distribusi penjualan, bukan kegiatan pemasaran.

e. Philip Kotler (Philip Kotler) dalam karyanya "Marketing Management Analysis, Planning and Control" definisi yang lebih luas dari pemasaran, yaitu: pemasaran adalah: proses sosial, individu dan kelompok untuk mendapatkan barang maupun jasa atau apa saja yang mereka butuhkan , Dan dapatkan. Apa yang mereka inginkan dengan bekerja sama dengan individu lain untuk menciptakan dan memelihara produk atau barang dan nilai. Dan kelompok lainnya.

f. Menurut definisi pemasaran William J. Stanton, ini adalah keseluruhan sistem kegiatan bisnis baik penjualan maupun pembelian barang yang dirancang untuk merencanakan, memberi harga dari produk yang dijual, mempromosikan dan mendistribusikan barang dan jasa yang memenuhi kebutuhan pembeli yang ada dan calon pembeli. Sehingga konsumen mendapatkan apa yang diinginkan

\footnotetext{
${ }^{2}$ Franck Cochoy, 'The American Marketing Association', Journal of Historical Research in Marketing, 6.4 (2014)

${ }^{3}$ Michael J Thomas, 'Marketing Management: Analysis, Planning and Control (Book)', Journal of Business, 40 (1967).
} 


\section{Tujuan Manajemen Pemasaran}

a. Menciptakan Permintaan atau Demand

Tujuan utama dari manajemen pemasaran adalah menciptakan permintaan dengan berbagai carauntuk memenuhi kebutuhan. Buat metode terencana untuk mengetahui preferensi atau kebutuhan dan selera konsumen atau pembeli akan barang atau jasa yang memenuhi kebutuhan pelanggan. Sehingga pelanggan tertarik untuk membeli barag di perusahaan

b. Kepuasan Pelanggan

Manajer pemasaran harus mempelajari kebutuhan pelanggan sebelum menyediakan barang atau jasa. Yang perlu dipahami adalah menjual barang atau jasa tidak sepenting kepuasan pelanggan. Pemasaran modern berorientasi pada pelanggan. Mulailah dan akhiri dengan pelanggan.

c. Pangsa Pasar atau Market Share

Setiap bisnis bertujuan untuk meningkatkan pangsa pasarnya, dalam hal ini yang dimaksud adalah rasio penjualannya terhadap total penjualan dalam perekonomian. Misalnya, Pepsi dan CocaCola saling bersaing untuk meningkatkan pangsa pasar dan meningkatkan daya saing dari konsumen. Untuk tujuan ini, mereka mengadopsi periklanan inovatif, pengemasan inovatif, kegiatan promosi, dan sebagainya untuk menarik perhatian dari pembeli atau konsumen.

d. Peningkatan Keuntungan

Departemen pemasaran adalah satu-satunya departemen yang memperoleh pendapatan dan keuntungan yang dihasilkan dari sebuah perusahaan. Keuntungan yang cukup mestinya diperoleh untuk menjual barang atau produk jualannya yang memenuhi persyaratan. Jika perusahaan tidak memperoleh hasil keuntungan yang lebih, maka perusahaan mereka tidak akan bertahan. Selain itu, 
laba sangat penting untuk pertumbuhan dan diversifikasi perusahaan untuk melanjutkan nasib dari perusahaan sendiri.

e. Pencitraan Produk yang Baik di Mata Publik

Membangun citra dan perhatian produk yang baik di mata publik adalah tujuan manajemen pemasaran yang penting lainnya. Jika departemen pemasaran menyediakan produk berkualitas tinggi kepada pelanggan dengan harga yang wajar, hal itu pasti akan membentuk citra dan kepercayaan yang baik di antara perusahaan dan pelanggan sendiri.

f. Menciptakan Pelanggan Baru

Buat pelanggan baru Bisnis didirikan untuk menjual barang, produk, jasa atau layanan kepada konsumen atau pelanggan. Oleh karena itu, pelanggan adalah hal yang paling penting dan utama bahasa sederhananya adalah fondasi perusahaan. Pelanggan memberikan pendapatan pada bisnis dan menentukan apa yang akan dijual perusahaan. Dan nantinya pelanggan adalah penentu dari kelanjutan bisnis pada suatu perusahaan.

g. Menciptakan pelanggan baru

Buat pelanggan baru Ini berarti mengeksplorasi dan mengidentifikasi kebutuhan pelanggan secara lebih luas. Jika sebuah perusahaan ingin mengembangkan dan mempertahankan bisnisnya, hal tentang menciptakan pelanggan baru sangatlah penting untuk menyebarkan barang yang dijualkan, dan Anda harus menganalisis dan memahami apa yang mereka butuhkan dan inginkan.

h. Memuaskan Pelanggan

Memuaskan pelanggan Menciptakan pelanggan baru saja tentu saja tidak cukup. Perusahaan harus bisa dan mampu mengembangkan dan mendistribusikan produk dan layanan yang memenuhi harapan dan keinginan mereka untuk memuaskan pelanggan atau konsumen. Jika pelanggan tidak puas, perusahaan tidak akan dapat menghasilkan pendapatan lebih untuk menutupi 
biaya dan memperoleh pengembalian modal yang wajar atau perusahaan tidak akan mendapat keuntungan yang diharapkan.

\section{Konsep Manajemen Pemasaran}

Falsafah konsep pemasaran bertujuan memberikan kepuasan terhadap keinginan dan kebutuhan pembeli/konsumen. Seluruh kegiatan dalam perusahaan yang menganut konsep pemasaran harus diarahkan untuk memenuhi tujuan tersebut.Secara definitif dapat dikatakan bahwa: Konsep Pemasaran adalah sebuah falsafah bisnis yang menyatakan bahwa pemuasan kebutuhan konsumen merupakan syarat ekonomi dan sosial bagi kelangsungan hidup perusahaan (Stanton, 1978).

Elemen Penting dalam Konsep Pemasaran:

a. Market oriented berorientasi pada keinginan Konsumen

b. Penyusunan kegiatan pemasaran secara terpadu

c. Pencapaian tingkat kepuasan Konsumen

Konsep Manajemen pada hakikatnya mencakup upaya dan strategi yang ditempuhmanajemen dalam rangka untuk mencapai tingkat kepuasan konsumen. Beberapa istilah yang sangat penting dalam konteks pemasaran

a. Produk (barang, jasa, ide); Segala hasil kerja manusia yang dapat ditawarkan kepada manusia lainnya baik berupa barang, jasa atau ide. Konsumen akan menyukai produk yang menawarkan mutu terbaik, kinerja terbaik dan sifat terbaik sehingga perusahaan harus memfokuskan diri pada perbaikan produk yang terus menerus, menyukai produk yang mudah diperoleh dan sangat terjangkau karenanya manajemen harus berfokus pada perbaikan efisiensi produksi dan distribusi.

b. Nilai; Perkiraan konsumen atas suatu produk untuk kepuasan mereka, apa yang dirasakan / diinginkan, perbedaan antara nilai yang dinikmati pelanggan karena memiliki serta menggunakan suatu produk dan biaya untuk memiliki produk tersebut 
c. Biaya; Harga yang harus dibayar konsumen atas produk yang dikonsumsi

d. Kepuasan; Seberapa puas konsumen atas produk yang mereka konsumsi (kesesuaian antara harapan dan kenyataan), Kepuasan (customer satisfaction): tingkatan dimana kinerja yang dirasakan (perceived performance) poduk akan sesuai dengan harapan seorang pembeli atau tidak

e. Pasar; Tempat yang berisi semua pelanggan potensial yang berniat untuk transaksi terhadap suatu produk.

4. Perencanaan Strategi Pemasaran

Perencanaan strategi pemasaran adalah salah satu kegiatan pokok yang dilakukan oleh perusahaan tertentu untuk mempertahankan suatu kelangsungan perusahaannya, untuk supaya berkembang, dan untuk mendapatkan suatu laba. Sangat harus diperhatikan dalam mencapai suatu tujuan pemasaran tersebut, maka dari itu suatu perusahaan harus memperhatikan strategi pemasaran. Strategi pemasaran adalah suatu rangkaian, tujuan, dan sasaran, kebijakan serta suatu aturan yang memberi arah kepada usaha-usaha pemasaran dari waktu ke waktu pada masingmasing tingkatan serta lokasinya. Strategi pemasaran merupakan hal yang sangat penting bagi perusahaan dimana strategi pemasaran merupakan suatu cara mencapai tujuan yang diinginkan dari sebuah perusahaan.

Penerapan strategi pemasaran melalui beberpa langkah sebagai berikut :

a. Segmentasi pasar ( market segmentation ), adalah tindakan membagi pasar menjadi kelompok pembeli berbeda dengan kebutuhan, karakteristik atau prilaku berbeda yang mungkin memerlukan produk atau bauran pemasaran terpisah.

b. Penetapan Target Pasar ( market targeting ), yaitu proses mengevaluasi daya tarik masing-masing segmen pasar dan memilih satu atau lebih segmen yang akan dilayani, penetapan sasaran pasar terdiri dari merancang sertategi untuk membangun hubungan yang 
benar dengan pelanggan yang tepat, atau sebuah perusahaan besar mungkin memutuskan untuk menawarkan ragam produk yang lengkap dalam melayani seluruh segmen pasarnnya, sebagian besar perusahaan memasuki pasar baru dengan melayani segmen tunggal, dan jika hal ini terbukti berhasil, mereka menambahkan segmen

c. Diferensiasi dan posisi pasar ( Differentiation and positioning), perusahaan harus memutuskan bagaimana mendiferensiasikan penawaran pasarnnya untuk setiap segmen sasaran dan posisi apa yang ingin ditempatinnya dalam segmen tersebut, posisi produk adalah tempat yang diduduki produk relative terhadap persaingan dalam pikiran konsumen, pemasar ingin mengembangkan posisi pasar unik bagi produk mereka. Jika sebuah produk dianggap sama persis dengan produk lainnya dipasar, konsumen tidak mempunyai alasan untuk membelinnya.

Beberapa strategi pemasaran :

a. Strategi pertama adalah melakukan promosi. Promosi adalah upaya untuk memperkenalkan sebuah produk bisnis kepada konsumen sebagai bagian dari strategi pemasaran, dari yang belum tahu menjadi tahu. Ada yang beranggapan bahawa produk yang berkualitas akan terjual dengan sendirinya. Tetapi, dalam strategi mempromosi, pemasar melaksanakan kegiatan memperkenalkan produk yang hendak ditawarkan kepada pengguna. Dalam usaha tersebut berbagai kaedah promosi perlu dilaksanakan agar pengguna mengetahui, memahami dan seterusnya membuat keputusan untuk menggunakan produk. Tanpa kegiatan promosi, pemasaran produk yang berkualitas pun tidak menjadi aktif dan industri sukar memperoleh tahap kompetitif yang dikehendaki di pasaran.

b. Strategi kedua adalah mengembangkan produk mencakup perubahan barang atau jasa dengan tetap menggunakan cara produksi lama. Umumnya strategi ini dilakukan untuk memperpanjang masa edar atau siklus hidup, bilamana perusahaan mengetahui bahwa sasaran 
pembeli mulai bosan dan perusahaan harus mengubah barang atau jasa yang ditawarkan tersebut. (Rchmad Gesa, 2015) ${ }^{4}$

c. Strategi ketiga adalah menerapkan biaya murah. Strategi ini didasarkan pada biaya input yang rendah sehingga dapat menghasilkan barang atau jasa yang murah juga, namun bukan berarti menawarkannya dengan kualitas yang rendah.

d. Strategi keempat adalah strategi menembus pasar untuk menjangkau sasaran pembeli yang belum tercapai. Strategi ini digunakan jika perusahaan masih banyak sasaran pembeli yang belum dapat dijangkau oleh barang atau jasa yang ditawarkan, atau masih banyak sasaran pembeli yang belum menggunakan barang atau jasa perusahaan. Strategi ini sebenarnya digunakan untuk meningkatkan penjualan dengan menawarkan barang atau jasa kepada sasaran pembeli yang sama, baik yang pernah menggunakan barang atau jasa perusahaan maupun yang belum.

\section{Adinda Konveksi}

Adalah perusahaan yang bergerak di bidang produk dan jasa pakaian/konveksi/mikro garmen yang berlokasi di jalan hoscokroaminoto RT 03 RW 01 Desa moyoketen kecamatan boyolangu kabupaten Tulungagung Jawa timur ndonesia. Pengalaman menekuni di bidang usaha konveksi ini sejak tahun 2001 telah memberikan banyak pelajaran berharga untuk senantiasa meningkatkan profesionalisme usaha dalam hal peningkatan manajemen usaha, sumber daya manusia, kualitas, produktifitas, ketepatan waktu dalam kerangka mewujudkan kepuasan mitra/konsumen.

Produk-produk ADINDA KONVEKSI antara lain Seragam Olah Raga, kaos, pakaian dalam, celana dalam . Produk ADINDA konveksi telah tersebar di beberapa daerah di indonesia seperti jawa, kalimantan , sumatera ,dan bali.

\footnotetext{
${ }^{4}$ Rachmad Gesah and Mukti Prabowo, 'Pengembangan Sistem', 2015.
} 


\section{Visi \& Misi ADINDA KONVEKSI}

1. Visi (Vision)

Menjadi Home Industry jasa konveksi/garmen berskala nasional dan international.

2. Misi (Mision)

a. Menyediakan produk dan jasa konveksi dengan kualitas produk yang berorientasi pada peningkatan citra, estetika dan customer brand konsumen.

b. Menjalin rantai nilai hubungan (Value Chain) antar stake holder yang berkesinambungan.

c. Membangun jaringan melalui mitra produk bermerek dan sistem kemitraan pemasaran berbasis internet.

d. Menjalin kemitraan, kesejahteraan bersama dan hubungan kerja harmonis berdasarkan prinsif-prinsif manajemen profesional dan semangat kebersamaan yang saling menguntungkan antar stake holder.

e. Melakukan peningkatan kualitas SDM pekerja melalui berbagai pendekatan edukasi yang sesuai dengan kebutuhan profesional pekerja.

\section{Pandemi Covid 19}

Pandemi covid 19 adalah pandemi yang disebabkan oleh virus SARS-Co-V-2 atau lebih dikenal dengan sebutan virus corona . corona terjadi pada awal bulan 2020 di daerah Wuhan China. Virus corona ini telah menginfeksi ratusan bahkan ribuan manusia tiap harinya. Virus corona ini menyebar melalui kontak fisik individu dengan individu lainnya bisa melalui hidung, mulut, dan mata kemudian virus tersebut berkembang pada paru paru manusia. Wabah covid ini membawa banyak perubahan yang signifikan sehingga pemerintah membuat peraturan tentang pembatasan aktivitas untuk mencegah penyebaran virus corona ini. Pemerintah 
memberikan protokol kesehatan yaitu mencuci tangan dengan sabun, memakai masker, dan menjaga jarak.

Pada Desember 2019, Kota Wuhan, Provinsi Hubei melaporkan kasus pertama pneumonia misterius. Sumber penularan kasus ini belum pasti, namun kasus pertama terkait dengan pasar ikan di Wuhan.1 Sejak 18 Desember hingga 29 Desember 2019, 5 pasien menerima pengobatan sindrom gangguan pernapasan akut (ARDS). Sejak 31 Desember 2019 hingga 3 Januari 2020, situasi ini meningkat pesat, sebanyak 44 kasus dilaporkan. Dalam waktu kurang dari sebulan, penyakit ini telah menyebar ke banyak provinsi lain di China, Thailand, Jepang dan Korea Selatan. Sampel yang diteliti menunjukkan etiologi virus korona baru. 2 Penyakit ini awalnya dinamai Novel Coronavirus 2019 (2019-nCoV) untuk sementara, dan kemudian Organisasi Kesehatan Dunia mengumumkan nama baru, Penyakit Coronavirus (COVID-19) pada 11 Februari 2020. Disebabkan oleh virus coronavirus 2 (SARS-CoV-2) sindrom pernapasan akut yang parah.

Virus ini dapat menyebar dari orang ke orang dan menyebar luas di China dan lebih dari 190 negara dan wilayah lain. Pada 12 Maret 2020, Organisasi Kesehatan Dunia mengumumkan pandemi COVID-19. Sampai dengan 29 Maret 2020 terdapat 634.835 kasus dan 33.106 kasus 5 Sementara di Indonesia terdapat 1.528 kasus Covid 19 positif dan 136 kematian.

\section{Metodologi Penelitian}

Dalam menyelesaikan penelitian yang diteliti oleh penulis kali ini, penulis menggunakan metode kualitatif. Penelitian kualitatif adalah suatu proses penelitian yang menghasilkan data deskriptif berupa kata-kata atau kata-kata dengan mengamati orang-orang dan tingkah laku. Peneliti tidak menggunakan angka atau rumus statistik saat mengumpulkan data dan memberikan hasil untuk penelitian. Dalam penelitian ini peneliti mencoba mendeskripsikan berbagai situasi, kondisi, atau fenomena yang ada. Format deskripsi kualitatif dirasa cocok untuk penelitian tentang isu-isu yang memerlukan penelitian mendalam, seperti penelitian tentang 
perilaku konsumen, pengaruh media, dan implementasi kebijakan. Dalam penelitian yang diteliti oleh peneliti kali ini, peneliti mencocokkan realitas empiris dengan teori-teori populer yang telah berlaku. Menurut pandangan Keirl dan Miller karya Moleong (2010 : 11 ), penelitian kualitatif berarti tradisi khusus dalam pengetahuan ilmu sosial, yang pada dasarnya bergantung pada observasi, manusia, bidangnya, dan pengetahuan yang berkaitan dengan bahasa dan terminologi orang-orang ini. Jenis dari penelitian yang diteliti penulis adalah deskriptif.

Penelitian ini dilaksanakan di Adinda Konveksi desa Moyoketen RT 01 RW 03 kecamatan Boyolangu kabupaten Tulungagung. Pada tanggal 05 Oktober 2020 s.d 31 Oktober 2020. Penelitian kualitatif tidak dimaksudkan untuk meringkas hasil penelitian. Hasil penelitian bersifat kontekstual dan akademis, dapat diterapkan pada waktu dan tempat tertentu dimana penelitian dilakukan. Besar kecilnya sampel tidak dapat mengukur baik atau tidaknya suatu penelitian, Dalam penelitian kualitatif istilah "sampel" tidak dikenal. Sampel dalam penelitian kualitatif disebut pemberi informasi atau objek penelitian, yaitu orang-orang yang dipilih untuk wawancara atau observasi sesuai dengan tujuan penelitian. Alasan disebut topik penelitian bukan karena whistleblower dianggap sebagai obyek yang secara aktif mengkonstruksi realitas, bukan sekedar obyek yang hanya mengisi kuisioner. Subjek dari penelitian ini adalah adinda konveksi sedangkan objeknya adalah menejemen pemasaran selama pandemi covid 19.

Untuk teknik pengumpulan data, peneliti akan melakukan interview sumber atau wawancara sumber kemudian observasi langsung di tempat terjadinya penelitian dan mengumpulkan dokumen dokumen pendukung untuk mengumpulkan data selama penelitian. Penulis hanya mengambil sampel kurang lebih selama satu bulan. Untuk instrumen penelitian kualitatif sendiri peneliti adalah intrumen riset yang paling utama untuk melangsungkan penelitian. Peneliti akan mengkaji, meneliti, dan menganalisis data secara detail dan mendalam tentang menejemn pemasaran Adinda Konveksi selama pandemi covid 19. Peneliti juga menggunakan buku pegangan untuk panduan penelitian lebih lanjut agar penelitian bisa berjalan dengan lancard dan berguna untuk mendukung validasi data yang diteliti oleh penulis. Kemudian peneliti akan menjelaskan data yang valid 
mengenai menejemen pemasaran Adinda konveksi selama pandemi covid 19. Kemudian catatan lapangan, Catatan lapangan adalah alat tulis yang digunakan peneliti untuk mencatat momen momen penting dan ringkasan selama melakukan Dokumentasi penilitian. Pedoman ini digunakan untuk mencatat dan mempelajari berbagai informasi yang relevan dari literatur seperti buku, arsip, jurnal, maupun dokumen di tempat kejadian penelitian. Dokumen dokumen ini akan membantu peneliti untuk menemukan data data penelitian yang dibutuhkan.

\section{Hasil Dan Pembahasan}

Setelah interview sumber dan observasi langsung peneliti akhirnya bisa menjelaskan hasil dan pembahasan dari penelitian kali ini. Peneliti melakukan observasi langsung di tempat Adinda Konveksi. Dari Hasil intervie sumber dari penelitian ini adalah Selama pandemi COVID-19 yang melanda dunia sejak awal tahun 2020 telah memberikan dampak yang cukup besar bagi perekonomian Indonesia, khususnya bagi usaha mikro, kecil dan menengah (UMKM). Seperti yang dialami ADINDA KONVEKSI selama pandemi ini, ternyata terdapat berbagai kendala yaitu penjualan yang menurun, distribusi yang terbatas dan kesulitan bahan baku. Dengan cara ini, pemilik bisnis dan karyawan yang kehilangan pendapatan dalam pandemi ini.

Problematika ini membuat pemilik usaha atau pelaku UMKM dituntut untuk bisa menemukan srategi dan ide ide baru. Begitu juga yang dilakukan oleh pemilik dari usaha UMKM Adinda Konveksi. Pemilik Adinda Konveksi mulai Memanfaatkan media sosial sebagai channel utama pemasaran. Di tengah himbauan menjaga social distancing, media sosial dapat menjadi salah satu cara dalam mempromosikan produk atau usaha yang Adinda Konveksi miliki. Banyak juga UMKM di Indonesia yang beralih mengunakan strategi penjualan online di situasi seperti ini dimana masyarakat meminimalisir interaksi langsung, perilaku berbelanja masyarakat pun ikut berubah. Banyak kegiatan maupun transaksi yang beralih ke online. Salah satu cara untuk menghadapi disrupsi ini adalah sigap beradaptasi dengan keadaan, seperti mengalihkan strategi penjualan ke online baik lewat website toko online ataupun media sosial. 
Tak hanya itu saja melakukan inovasi produk berdasarkan kebutuhan Permintaan masker kain yang meningkat selama pandemi membuat banyak brand fashion pun banting setir menciptakan produk-produk yang diinginkan masyarakat juga sangatlah penting. Membuat inovasi produk berdasarkan kebutuhan adalah salah satu strategi untuk bertahan di tengah pandemi. Tetapi juga memperhatikan standar kualitas produk dan membuat paket ekonomis agar produk bisa bertahan . Adinda Konveksi sudah mulai memanfaatkan apa yang ada disekitarnya contohnya media sosial. Karena semenjak diberlakukannya social distancing penjualan melalui media online adalah cara yang paling efektif untuk mempertahankan usaha.

Adinda Konveksi mulai menggunakan media sosial atau media online dengan promosi barang atau produk yang dihasilkan. Adinda Konveksi berupaya untuk memperkenalkan sebuah produk bisnisnya ini kepada konsumen sebagai bagian dari strategi pemasaran, dari yang belum tahu menjadi tahu. Sehingga banyak sekali masyarakat yang sudah mulai mengetahui umkm Adinda Konveksi dan produk yang mereka jual. Meski pada awal saat promosi pemilik dari Adinda koveksi mengalami kendala yaitu kurangnya konsumen yang tertarik pada produknya namun pemilik dari adinda konveksi sendiri tetap mencari ide ide kreatif baru untuk menarik perhatian pelanggan.

Setelah itu Adinda Konveksi mulai menggunakan beberapa aplikasi untuk membuat karya produknya lebih menarik lagu sebagai promosi. Mereka menggunakan media sosial website, instagram, facebook dan whatsapp. Mereka juga membuat produk produk yang sedang hype dikalangan masyarakat. mereka memperbarui packaging agar lebih terlihat menarik dan tidak terkesan itu itu saja. Selain itu Adinda Konveksi juga kerap membeeikan diskon diskon pada produknya agar konsumen lebih tertarik untuk membeli produknya. Namun dengan adanya diskon ini Adinda Konveksi tetap memperhitungkan keuntungan sehingga usaha yang mereka bangun tetap bisa bertahan meskipun tengah dilanda pandemi virus corona. adinda Konveksi juga tetap menerapkan metode survei untuk mengatur menejemn pemasaran produk usahanya. Sehingga seriring berjalannya waktu Adinda Konveksi mulai dikenal banyak khalayak dan mulai banyak pembeli dan langganannya. Karena selain produk dari Adinda konveksi adalah home industry 
yang menjual produk cukup murah namun kualitas dari produknya tetap terjamin dan tidak kalah dengan produk produk lainnya. Sehingga sangat efektif untuk dijual melalui media online.

Adinda Konveksi harus tetap mempertahankan menejemen pemasaran yang telah ia bangun untuk mempertahankan usahanya. Karena Menurut statistik tahunan Orang Indonesia di 2019 yang menggunakan pemasaran online hanya Sekitar $15,08 \%$ dari total keseluruhan Pemasaran online. Oleh karena itu pemasaran online adalah salah satu Teknik yang efektif pada saat ini terutama di era itu Revolusi Industri 4.0. Menurut hasil penelitian kuantitatif yang dilakukan oleh Setiawati, pemasaran online berpengaruh positif terhadap pertumbuhan laba UMKM di Jawa Tengah. Dalam penelitian ini, data yang diperoleh merupakan data utama yang diperoleh dengan mengirimkan kuesioner kepada responden secara online dan offline. Mengingat banyaknya pengguna internet di Indonesia, sistem pemasaran online ini dapat meningkatkan kesejahteraan masyarakat. Dengan memaksimalkan pemasaran online di bidang UMKM maka keuntungan penjualan akan meningkat. Adinda konveksi juga mendapatkan pelanggan tidak hanya dari sekitar kotanya saja melainkan juga diluar kota karena media online sendiri memiliki banyak sekali pengguna dari seluruh kalangan masyarakat

Sistem pemasaran online memiliki berbagai jenis manajemen, dan diyakini bahwa strategi pemasaran online dengan menggunakan Instagram dan Facebook sangat efektif. Mereka menggunakan situs web dan pasar untuk mengarahkan pembeli langsung ke media sosial mereka. Dengan cara ini, lalu lintas pengunjung Instagram dan Facebook mereka secara otomatis akan meningkat drastis. Sistem promosi yang mereka gunakan adalah sistem pengiriman berita dan kupon online. Selain itu, mereka juga melakukan promosi dalam bentuk hadiah dan pengakuan. Strategi lain yang ditempuh oleh fashion adalah memperbanyak jenis dan variasi produk. Hal ini terlihat dari perkembangan toko yang semakin pesat, seiring dengan bertambahnya variasi dan koleksinya. Selain promosi dan Endorsement, mereka juga memberikan jaminan jika terjadi kesalahan produk atau cacat produk selama pengiriman. Dengan media online seperti facebook dan website tersebut banyak 
sekali khalayak yang sudah mengenal Adinda Konveksi dan banyak sekali yang mengunjugi situs milik Adinda Konveksi sendiri.

Ada beberapa strategi baru yang bisa di gunakan serta di praktikan oleh UMKM yaitu dengan pengubahan metode atau model penjualan yang dulunya hanya stnd toko menjadi online atau ecommerce, melakukan suatu pemasaran produk mereka secaradigital dan membangun suatu branding produk atau barang yang di produksi dari perusahaan untuk mengenalkan dan menyebarkan keciri khasan dari produknya, peningkatan kualitas produk maupun jasa demi kenyamanan serta menciptakan relasi dan hubungan baik kepada masyarakat khususnya pelanggan agar tingkat kepercayaan dari konsumen meningkat seiring berjalan waktu usaha penjualan. Jika strategi tersebut dapat diterapkan secara optimal dan maksimal maka UMKM bisa berjalan dengan baik dan lancar serta tidak mengalami kerugian. Media online atau e-commerce memiliki banyak sekali dampak dan pegaruh positif sebagai media pemasaran usaha baik perusahaan maupun usaha UMKM apalagi selama pandemi covid 19 yang mengharuskan seluruh manusia untuk menetapkan protokol kesehata yang sudah ditetapkan.

UMKM Adinda Konveksi juga menggunakan media online dan e-commerce untuk menejemen pemasarannya. Mulai dari perkenalan produk buatannya yang berupa pakaian dan lain sebagainya hingga pada proses jual beli dan membangun relasi yang baik antara pemilik dan team dari Adinda Konveksi dan konsumen senhingga mereka menjadi pelanggan yang menaruh kepercayaan penuh pada UMKM Adinda Konveksi. Dengan bejualan mellui media online Adinda konveksi tetap memfokuskan diri untuk menjadi penyedia produk dan jasa konveksi yang berorientasi pada kepuasan pelanggan. Dalam strateginya sendiri adinda konveksi menggunakan konsep sesuai dengan produknya yaitu Produk harus bersifat handal, stabil, simple, fleksible, uptodate, kompetitif dan memudahkan pengguna produk. Produk Konveksi harus murah sehingga semua instansi dan bidang usaha dapat menggunakan produk konveksi, produk Konveksi harus sesuai dengan keinginan dan kebutuhan konsumen. Produk memiliki kelebihan di bandingkan dengan produk lain, baik kualitas, kuantitas, delivery dan distribusi. 


\section{Kesimpulan}

Dari hasil penelitian yang telah dipaparkan peneliti. Dengan demikian dapat ditarik kesimpulan bahwa 2020 menjadi tahun terberat dalam dunia wirausaha akibat pandemi Covid-19 yang sudah ada sejak akhir tahun 2019 yang memaksa setiap usaha untuk memutar haluan strategi. Tidak sedikit juga yang mengalami krisis di saat pandemi, sehingga beberapa perusahaan sudah merumahkan karyawannya untuk mengurangi beban pembiayaan. Sektor bisnis yang paling banyak terkena imbas adalah sektor penerbangan komersial, travel, minyak dan gas bumi, otomotif dan perbankan. Namun bisnis sektor UMKM juga terkena dampak karena masalah ketersediaan bahan baku dan juga peraturan pembatasan sosial.

Hampir semua pelaku usaha di sekotor UMKM ini mengalami penurunan omzet penjualan yang sangat drastis, mengalami berbagai kendala pemasaran dan penjualan, juga distribusi produk. Di satu sisi para pelaku usaha mengupayakan untuk menemukan alternatif pemasaran dan penjualan, mengamankan modal dan aset, mengalihkan sementara untuk usaha lainnya, dan harus mempelajari teknologi yang dipandang efektif untuk melakukan promosi dan penjualan. Para pelaku usaha di sektor UMKM ini berupaya mempertahankan bisnis atas usahanya di tengah pandemi Covid 19 dengan tetap mengikuti aturan pemerintah dan protokol kesehatan serta keamanan dengan berbagai upaya yang diamati, diidentifikasi, membuat keputusan, dan melakukan aktivitas kembali dengan terus melakukan observasi, mengidentifikasi, membuat keputusan, dan bertindak secara terus menerus dalam satu siklus yang tidak dibatasi waktu.

Di masa pendemi covid 19 perkembangan digital dalam globalisasi semakin berkembang. Oleh sebab itu seharusnya ADINDA KONVEKSI merubah pola pemasaran menjadi moderen sehingga penjualan roda pendapatan bagi pengusaha menjadi lebih baik .seperti yang terjadi sekarang di kala sosial distancing dan pembatasan wilayah terjadi dimana- dimana menyebabkan banyak pengusaha mengalihkan konsumennya ke era belanja online seperti pasar digital, di Facebook, Google, You Tube , instalgram shoope dan masih 
banyak lainnya . Berikut ini keuntungan berbelanja online bagi para konsumen

- Minimalkan Biaya

Efisiensi biaya dan waktu menjadi faktor utama melakukan transaksi online. Selain lebih efisien dari segi biaya, antara lain biaya transportasi, biaya parkir, dan biaya akomodasi yang merupakan satu paket dengan proses transaksi. Belum lagi dari segi efisiensi waktu, anda perlu harus meluangkan waktu khusus untuk melakukan aktifitas belanja, terlebih menghabiskan banyak waktu lagi untuk memilih dan mencari barang, sehingga perlu tenaga fisik yang kuat.

- Kurangi Kelelahan

Dalam transaksi pasar online, anda tidak perlu harus repot mendatangi toko, mall dan lain sebagainya . Sehingga kita tidak harus capek dan mengeluarkan tenaga ekstra belum lagi penerapan sosial distancing yang menyebakan konsumen hati- hati dalam menjaga jarak. Jika transaksi secara online, kita bisa berbelanja sambil melakukan aktifitas lain dirumah, atau tempat kerja, sehingga dinilai sangat praktis.

- Efesiensi Daya

Aktifitas belanja melalui digital juga efisiensi dari segi daya, dengan belanja via online yang hanya dengan satu aktifitas membuka smartphone semua aktifitas belanja mulai memilih toko, memilih barang hingga proses transaksi dan pembayaran dilakukan hanya dengan satu klik. Tentu hal ini menjadi sebuah kemudahan tersendiri dalam era masyarakat millenial.

- Terhindar dari Masalah Kerepotan

Jika berbelanja online saat customer ingin berbelanja banyak tidak perlu direpotkan membawa atau mencari kuli angkut untuk membawa kekendaraan atau kerumah kita, karena semua barang pesanan langsung dikirim kerumah dengan keadaan yang aman.

- Tidak Lapar Mata 
Salah satu faktor kelemahan seorang manusia dalam aktifitas belanja adalah nafsu belanja lebih saat di tempat perbelanjaan. Banyak kasus ketika hanya ingin membeli satu barang namun sesampai di toko bisa tertarik dengan barang lain yang sebenarnya tidak menjadi niat awal untuk membelinya. Ketika belanja online tentu hal ini bisa diminimalisir sebab kita akan bisa fokus mencari barang yang dibutuhkan.

- Diskon Menarik/Harga Spesial

Sistem belanja online semacam sistem tabungan, jadi semakin sering berbelanja online, penjual akan memberikan voucher, gift, poin, atau reward tertentu sebagai bukti terima kasih atas kepercayaannya. Berbeda dengan toko konvensional yang hanya memberikan potongan tertentu pada yang punya member saja atau pada saat tertentu.

- Efesiensi Waktu

Aktifitas belanja online jga tidak akan menghabiskan waktu kita, karena kita dimudahkan untuk tidak harus keluar, macet dijalan, dengan beragam bahaya di perjalanan. Dan aktifitas belanja online hanya membutuhkan waktu beberapa menit saja, sehingga waktu kita akan bisa diunakan untuk kegiatan yang lainnya.

- Faktor Kenyamanan

Faktor kenyamanan tentu tidak diragukan lagi, apabila elanja online kita tidak perlu harus berdandan, keluar untuk belanja, bahkan dengan posisi santai saja kita sudah bisa melakukan aktifitas belanja, bahkan belanja juga bisa tengah malam dan waktu libur. Banyak keuntungan yang ditawarkan cara belanja online harus ada beberapa langkah untuk dapat mempertahankan eksistensinya di pasar di era digital.

Dengan demikian para konsumen akan lebih tertarik dan meminati berbelanja online dari pada belanja langsung . sehingga para UMKM dapat menjual produk- produk tanpa harus menyebar brosur dan bisa memaksimalkan pasar digital secara maksimal serta tidak perlu bingung dengan cara pemasaran juga. 


\section{DAFTAR PUSTAKA}

Chochoy, F. (2014). The American Marketing Association. Journal Of Historical Reseach In Marketing, 6-4.

Kotler, P. (1994). Marketing Management Analysis Planning Impelementatiton And Control. Journal Of Retailing, 88(3).

Rchmad Gesa, M. P. (2015). Pengembangan Sistem.

Thomas, M. J. (1967). Marketing Management: Analysis, Planning And Control. Journal Of Bussiness, 40. 